\title{
BULGARIAN EMPLOYMENT POLICY: PRIORITIES AND DIRECTIONS 2017
}

\author{
Ekaterina Arabska \\ University of agribusiness and rural development - Plovdiv, Bulgaria \\ Faculty of economics and management, Department of management \\ 78, Dunav Blvd., Plovdiv 4003, Bulgaria \\ katya.arabska@gmail.com
}

Professional Paper

doi:10.5937/jouproman5-13668

\begin{abstract}
Development of labor market and employment policy in Bulgaria in contemporary dynamic conditions of social and economic life is in close relation to the European policies and programs and the needs of creating conditions for raising the level of employability of some special target groups on the labor market determined as the most vulnerable and needing particular measures of support. Current study makes analyses of priorities and directions in Bulgarian national employment policy for 2017 as set into the National action plan on employment considering a number of strategic and legislative documents on both national and European level. The general conclusions are focused on the systematization of actions and the importance of social dialogue.
\end{abstract}

Key words: employment, unemployment, labor market, active policy.

\section{Introduction}

Labor market development and employment policies in Bulgaria have been subjects to research about the peculiarities in national scope (Terziev \& Dimitrova, 2014; Terziev \& Dimitrova, 2015; Terziev \& Arabska, 2015c), importance of active policies (Arabska, 2016a; Terziev \& Arabska, 2015a; Terziev, Dimitrova \& Arabska, 2015; Terziev, Dimitrova \& Stoyanov, 2015), role of public employment services (Terziev \& Arabska, 2015b; Terziev \& Arabska, 2015d); labor market and sustainable development (Arabska, 2016b; Arabska, 2017). Labor market and policies have been examined from the initial years of its establishment during the transition period to a market economy through the period of European integration till the years of economic crises and next recovery. Current paper is focused on some specific features of employment policy for 2017 in consideration of European and national policies and strategic priorities of sustainable development.

To support member states' efforts to increase employment, promoting lifelong learning and social inclusion various European initiatives will be implemented in 2017. It is planned to launch a new initiative to stimulate the process of convergence between member states and strengthening the social dimension of the EU - European pillar of social rights. The main objective of the European pillar of social rights is to address gaps in legislation and to establish common principles and benchmarks with a view to greater convergence between member states in the field of employment and social inclusion. The policy areas are grouped in three main topics: equal opportunities and access to the labor market; fair working conditions; adequate and sustainable social protection. Within these three themes 20 policy areas have been identified related to different principles arising from certain rights enshrined in EU law and in other relevant sources of law. After its adoption the pillar of social rights will be a reference framework for monitoring social outcomes and results in employment achieved by the participating member states and to move the reform process at national level. 
In 2017 the implementation of the EU Recommendation for integrating long-term unemployed in the labor market will continue, adopted by the EU Council on February 15, 2016. Key action areas under which actions should be taken are:

- $\quad$ Promoting the registration of job seekers in employment services, as well as of economically inactive persons, incl. discouraged.

- Offering a job agreement to registered long-term unemployed persons who are not covered by the Youth Guarantee, at the latest upon reaching 18 months of unemployment registration. The agreement should include objectives, schedules, obligations that registered longterm unemployed person must meet and the services offered according to individual circumstances and needs.

- $\quad$ Defining a single point of contact to assist registered long-term unemployed through coordinated provision of services in the field of employment and social assistance.

- Implementation of closer relations with employers in order to increase the chances of finding a job for the registered long-term unemployed, incl. developing partnerships, development of services for employers such as mentoring in the workplace, training and support after recruitment, etc.

Considering the progress at the European level in reducing youth unemployment in the autumn of 2016 the European Commission has proposed increasing the budget allocation for the implementation of the national guarantee schemes for youth. An additional 1 milliard euro will be provided through the Youth employment Initiative for the period 2017-2020. With these, and 1 milliard euro from the European Social Fund, support will be rendered to about 1 million young people more to 2020 in the member states with the highest youth unemployment.

In 2017 the Commission intends to intensify its efforts to support young people through the European solidarity corps. The corps will provide the socially engaged young people under 30 years of age, whether they benefit from a guarantee youth or not, the opportunity to help and support other people and acquire new skills and experience, either in their country of origin or another member state. The corps is be based on existing professional and voluntary EU programs for youth, as well as the mobilization of established networks for employment, education and civil society across Europe.

In relation to achieving the Europe 2020 targets for growth, employment and competitiveness, on June 10, 2016 the European Commission adopted a new program for skills in Europe - the New Skills Agenda for Europe, which aims to strengthen human capital, ability to employment and competitiveness of the labor force in Europe. The program should provide maximum access to all learning, supporting training, acquisition of new qualifications and skills development for better preparation for the labor market. Approach will be oriented to meet the needs of both individuals and businesses. The new program for skills in Europe calls for commitment and cooperation of all key institutions, social partners and businesses to: improve the quality and relevance of skills acquired; ensure greater transparency and comparability of skills; raise skill levels and communicate better choice of career.

For the realization of initiatives under the new program for skills in Europe will be used as the main source of financing: European Social Fund, EU Program for Employment and Social Innovation (EaSI), European Regional Development Fund, EU program for education, training, youth and sport Erasmus+, Asylum, Migration and Integration Fund (AMIF), the European Fund for strategic investment and others.

In 2017 he will complete preparations for the first Bulgarian Presidency of the EU (January-June 2018). 
In this context it will be crucial for the adoption of the program priorities of the Presidency Trio (Estonia-BulgariaAustria), which will identify key areas that will seek progress in employment and workforce skills.

The specific recommendations of the Council of the EU to the individual member states determine priority areas for action at national level to address the essential challenges in the member state. In the Council Recommendation of 12 July 2016 on the 2016 National Reform Program of Bulgaria and delivering a Council opinion on the 2016 Convergence Program of Bulgaria in the labor market during the period 2016-2017 Bulgaria should take the following actions: to strengthen and integrate social assistance, including relevant social services and active employment policies, especially for long-term unemployed and young people who do not participate in any form of employment, education or training; to increase the provision of quality education for disadvantaged groups, including Roma; in consultation with the social partners to draw up guidelines and criteria for determining the minimum wage; to increase the scope and adequacy of the general scheme of minimum income.

Policies and concrete measures that will support the implementation of specific recommendations to Bulgaria in the field of labor market are included in the National plan action plan on employment for 2017. It will be the mechanism for adjusting the labor market towards sustainability, balance and better functioning. The aim is to support favorable employment growth in the economy to balance labor market, preparing personnel for jobs and professional fields with unsecured demand. Along with this it will provide activation of inactive and proactive training of workforce to increasing demand by businesses and better adaptation of the economy to external and internal challenges of economic development. The plan will continue to contribute to the realization of the goals and commitments of the country in implementation of the EU Strategy 2020 and the measures included in the National Reform Program 2016 2020, Convergence Program 2017 - 2020, the tasks of the updated Employment Strategy 2013 - 2020, National Plan for implementing the European Youth Guarantee 2014 - 2020, National Strategy for Lifelong Learning 2014-2020, National Strategy for Persons with Disabilities 2016-2020, the National Development Program: Bulgaria 2020 and others.

\section{Material and methods}

The study presents the analyses made on priorities and directions in Bulgarian national employment policy according to the relevant strategic and legislative documents providing the bases, objectives and actions in active policies on labor market in conditions of globalization and in the context of the sustainable development.

\section{Results and discussion}

In setting policies and measures on labor market it is important to have comprehensive information and analyses on trends and future needs. Key issues and challenges in the labor market for 2017 are determined as follows in the National action plan on employment:

- $\quad$ Significant imbalances in supply and demand for labor in terms of knowledge and skills of job seekers and regions. It is necessary to seek solutions to the problem through changes in education, proactive learning, trainings for employees, etc.

- In less developed regions the number of new jobs remains insufficient, despite a recovery in the economy. It is necessary to adequately address the problem of displacement of vacancies for those with low skills from highly qualified unemployed. 
- The number of unemployed persons from disadvantaged groups, despite some positive trends, remains high. This is especially the case for young people with low education and no job, inactive youths (NEET's), long-term unemployed, unemployed over the age of 50, unemployed Roma without qualification and with low education, as in these disadvantaged groups there are limited opportunities to get out of the "poverty trap" and dependence on social welfare system. This requires more work with a significant number of people of these groups for activation, motivation for active behavior on the labor market, including literacy training;

- $\quad$ Reserve of the workforce - inactive persons, incl. discouraged, despite their decline, remains high. Along with the need for activation of these groups, it is appropriate to actively work with employers to motivate this reserve and its orientation towards employment in occupations with high demand and insufficient supply, including by providing opportunities to encourage mobility, reconciliation of family and professional life, flexible work, working part-time, etc.

- The adopted large number of refugees in European countries, employing many Bulgarians, will include into the labor markets of these countries an additional inflow of job seekers who need to be integrated, which will increase competition in the jobs for unskilled labor.

- Industrial relations adapt slowly to changes in the labor market that is becoming increasingly diverse, globalized and unconventional.

- $\quad$ The phenomena of gray economy in employment, despite their allocated limit as a result of the joint efforts of the institutions and social partners, remains an important problem - including remuneration on that taxes and insurance are not charged, overtime unpaid work, delay payment of wages and others.

"Bottlenecks" in the labor market could be determined as follows:
- Low economic activity compared with other member states.

- Unsecured demand for skilled workers in occupations and industries with potential for development and crucial to the economy, in cases in which the absorption of knowledge and skills requires a longer period.

- $\quad$ Brevity in employment in the active season in basic economic activities, such as construction, agriculture, tourism and others, and an extended idle period during the year with an increase in unemployment.

- An increased risk of social exclusion and poverty for the working population from small towns and rural areas, which population is with low economic activity, low labor mobility and lack of motivation to work at low cost.

- Low employment of persons with disabilities due to inaccessible environment, conditions and hours of work and others.

- Low income restricting flexible forms of employment, incl. part-time work for a period of time when the workplace is in another locality of residence of the unemployed or inactive person and has high transportation costs.

In relation to all these, the vision of the National action plan for employment in 2017 is defined as: support to increase the growth potential of the economy by providing quality workforce and increasing employment quality jobs in the real economy of jobseekers with a focus on disadvantaged groups in the labor market and priority of the least developed areas.

In this regard, the task of the active policy on the labor market is to help reducing imbalances in the labor market as the integration of the supply and demand of labor (in quantity, quality and spatial distribution) and providing faster and qualitative transitions from unemployment and inactivity to employment through the development of services and cooperation with partners in the labor market. 
Supporting the unemployed in job search, including in education and employment of the most vulnerable groups of unemployed ensuring social inclusion for these groups, earned income and social security rights, revenues from taxes and social security payments to the state. Taking part of the personnel costs of businesses, especially SMEs, is to support and promote job creation in them. Support will be given to investments in areas with high unemployment.

The provision of training and employment for disadvantaged groups is a chance to get out of the trap of poverty and the realization of some of the tasks of the social economy.

The main objectives and priorities of national employment policy in 2017 include:

- $\quad$ Reducing imbalances between supply and demand for labor and support for job creation in the real economy for growth conducive to employment. Improving the business environment and increase employment in basic and high growth sectors of the economy, limiting the informal employment and undeclared payments and improving the quality of employment in small and medium enterprises. Reducing disparities in employment between regions.

- Improving the quality of the workforce and increasing the supply of qualified personnel according to the demand of the business. Increasing participation in the labor market and reducing the number of inactive people of working age.

- Better integration and mastering skills of the unemployed from the most disadvantaged groups, faster job placement and achievement of sustainable employment. Achieving the objectives of the European Youth Guarantee and accelerating the reduction in youth unemployment, especially in the group of inactive youths (NEET's). Reducing the number of long-term unemployed and implementation of the Council Recommendation on this target group.

- $\quad$ Achieving efficiency and quality of employment services, including through closer cooperation with business, better cooperation with private employment agencies and enterprises providing temporary work. Achieving a lasting effect on integration into the labor market of the most vulnerable groups by providing integrated services of territorial divisions of the Employment Agency and the Social Assistance Directorates. Increasing the impact of programs, projects and measures of active policy on the labor market based on the results of the evaluations and improve the financial efficiency of spending.

- Development of inter-institutional relations and social partnership.

- Reducing unemployment by informing jobseekers for vacancies across the country, providing training, promoting internal mobility, inclusion in the temporary employment of a number of unemployed in areas with poor economic environment, providing retraining and intermediary services for fast transition to new employment for exempt staff of enterprises in difficulty and or ceased operations.

Priority target groups as recommended by the EU Council in 2016 are: long-term unemployed; young people who do not participate in any form of employment, education or training; Roma; marginalized groups. In 2017 active policy on the labor market will focus on some key target groups and subgroups (Table 1). 
Table 1. Target groups of the active labor market policy

\begin{tabular}{|l|l|}
\hline Target groups & Subgroups \\
\hline Unemployed youths up to 29 years & $\begin{array}{l}\text { unemployed up to 25 years; } \\
\text { youth who neither study nor are busy (NEET's); } \\
\text { youths earlier dropped out of the education system; }\end{array}$ \\
\hline Long-term unemployed & $\begin{array}{l}\text { unskilled and poorly educated; } \\
\text { unemployed Roma; } \\
\text { unemployed on social assistance; }\end{array}$ \\
\hline Unemployed over the age of 50 & $\begin{array}{l}\text { unskilled and low education; } \\
\text { in retirement age; } \\
\text { with unintended profession and specialty by employers; }\end{array}$ \\
\hline $\begin{array}{l}\text { Unemployed without occupation, without } \\
\text { qualification or no demanded professional } \\
\text { qualifications on labor market }\end{array}$ & $\begin{array}{l}\text { unemployed people without qualifications in regions with an } \\
\text { unemployment rate above the national average; } \\
\text { unemployed having shortages of key competencies; } \\
\text { unemployed with low education (including Roma); } \\
\text { unemployed on social assistance; }\end{array}$ \\
\hline Unemployed persons with disabilities & unemployed people without qualifications \\
\hline $\begin{array}{l}\text { Inactive persons wanting to work, incl. } \\
\text { discouraged people }\end{array}$ & $\begin{array}{l}\text { in regions with an unemployment rate above the national average; } \\
\text { unskilled and low education; } \\
\text { a period of inactivity for more than two years; }\end{array}$ \\
\hline
\end{tabular}

Each group will be approached by a differentiated way considering the subgroups in it. Individuals from these groups will be involved in training programs and measures after developing individual plans in which the actions will be determined according to the profile of the person and his/her chances for employment. Other groups are also embraced by the active policies (according to the implemented programs, schemes and measures of the Law on Employment Promotion) unemployed entitled to social assistance; unemployed registered for over six months, start-up entrepreneurs; employed persons with appropriate training; unemployed persons - single parents (adoptive parents) and / or mothers (adopters) with children up to age of 5; persons served their sentences; persons who have been granted refugee or humanitarian status. Some of these groups are less numerous, but that does not diminish the impact of their integration.

The National action plan for employment in 2017 includes activities in the following areas:

- Support for economic growth conducive to employment, improving the business environment, providing manpower for the development of basic and high growth industries. Limitation of informal employment and undeclared payments to workers.

- Improving the social dialogue through the involvement of social partners in the formulation and implementation of employment policies.

- Reduction of unemployment in the economically less developed regions, including through active policy on the labor market.

- Improving the functioning of the labor market: improving the activation of the unemployed, advice and guidance to the demanded on the labor market professions and specialties for quick transition to new jobs and reducing unemployment duration; activation of inactive persons, including discouraged; promoting internal mobility; implementation of the European Youth Guarantee; providing workforce with training and skills to the demands of business and in view of future needs according to short and medium-term forecasts; providing employment for disadvantaged groups in the labor market in programs, projects and measures under the Law on Employment Promotion; 
improvement of social security and social inclusion; income policy and passive policies of the labor market; free movement of workers within the EU and creation of conditions of employment for persons from third countries.

- Strengthening the management of employment policies: increasing the capacity of the Employment Agency and its cooperation with private employment agencies; development of the scope of control of the General Labor Inspectorate.

\section{Conclusion}

The priorities and directions of national employment policy in the Republic of Bulgaria for 2017 in accordance to the implementation of EU and national strategic objectives are the following:

- Support for economic growth conducive to employment, improving the business environment, development of basic and high growth sectors of the economy: support employment in SMEs; reduction of informal employment and undeclared payments to employees; active policy on the labor market in the economically less developed areas.

- Improving the functioning of the labor market, including through active social dialogue: improve the activation of the unemployed, incl. activation of discouraged persons, vocational guidance and counseling; implementation of the European Youth Guarantee; providing workforce training and skills to the demands of business and in view of future needs according to short and long-term forecasts of the labor market; providing employment for disadvantaged groups in the labor market in programs, projects and measures under the Law on Employment Promotion; providing social security and social inclusion, income policy and passive policy; free movement of workers within the EU and conditions of employment for persons from third countries.
- Improving social dialogue involving the social partners in the formulation and implementation of employment policies.

Social partners will continue to play an essential role in the efforts of overcoming the misbalances on the labor market with their potential impact in the prevention of redundancies, determining skills needs of the workforce, competence assessment, training of unemployed people and assisting in their recruitment, quality and practically oriented training, providing knowledge and skills in line with business needs, training of unemployed people from disadvantaged groups in order to activate and improve their employability, informing citizens about the protection of their labor rights and curb undeclared employment, motivation for active behavior on the labor market, assisting supported employment, literacy, vocational guidance, vocational training and key competencies, training of unemployed persons from vulnerable groups, supporting the recognition of professional knowledge, skills and competences acquired through non-formal education or learning, and many others.

\section{References}

[1] Arabska, E. (2016a). Active Social Policies - Insights in Developing a Functioning Labor Market. Balkan and Near Eastern Journal of Social Sciences BNEJSS 2016 (02) 03, pp. 47-63.

[2] Arabska, E. (2016b). Problems of Employment and Unemployment in Bulgaria: Is Sustainable Development Possible? Balkan and Near Eastern Journal of Social Sciences (BNEJSS), Vol. 2, N 1, pp. 6-19.

[3] Arabska, E. (2017). Labor Market and Sustainable Development: Bulgarian Experience. International Balkan and Near Eastern Social Sciences Conference Series, IBANESS Conference Series-Edirne, Turkey, 4 - 5 March 2017, Conference Proceedings, pp. 982-993.

[4] Asylum, Migration and Integration Fund (AMIF): $\quad$ https://ec.europa.eu/homeaffairs/financing/fundings/migrationasylum-borders/asylum-migrationintegration-fund_en. Accessed: 09/04/2017. 
[5] Convergence Program of the Republic of Bulgaria 2017-2020: http://www.minfin.bg/en/page/868.

Accessed: 09/04/2017.

[6] Council Recommendation of 12 July 2016 on the 2016 National Reform Programme of Bulgaria and delivering a Council opinion on the 2016 Convergence Programme of Bulgaria (2016/C 299/08).

[7] Council recommendation of 15 February 2016 on the integration of the long-term unemployed into the labour market (2016/C 67/01).

[8] EU programme for education, training, youth and sport Erasmus+: https://ec.europa.eu/programmes/erasmusplus/node_en. Accessed: 09/04/2017.

[9] EU Strategy 2020: http://ec.europa.eu/europe2020/index_en.ht $\mathrm{m}$.

[10]European Commission. Employment, Social Affairs \& Inclusion. ESF - European Social Fund: http://ec.europa.eu/social/main.jsp?catId=3 25. Accessed: 09/04/2017.

[11]European Commission. Employment, Social Affairs \& Inclusion. EU Programme for Employment and Social Innovation (EaSI):

http://ec.europa.eu/social/main.jsp?catId=1 081. Accessed: 09/04/2017.

[12] European Commission. Employment, Social Affairs \& Inclusion. European Pillar on Social Rights: http://ec.europa.eu/social/main.jsp?catId=1 226\&langId=en. Accessed: 09/04/2017.

[13] European Commission. Employment, Social Affairs \& Inclusion. New Skills Agenda for Europe: http://ec.europa.eu/social/main.jsp?catId=1 223. Accessed: 09/04/2017.

[14]European Commission. Employment, Social Affairs \& Inclusion. Youth Guarantee:

http://ec.europa.eu/social/main.jsp?catId=1 079. Accessed: 09/04/2017.

[15]European Commission. Growth. Industry. Innovation. Funding for innovation. European Fund for Strategic Investments: http://ec.europa.eu/growth/industry/innovati on/funding/efsi_en. Accessed: 09/04/2017.

[16] European Commission. Regional Policy Funding European Regional Development Fund:

http://ec.europa.eu/regional_policy/en/fundi ng/erdf/. Accessed: 09/04/2017.
[17]European Solidarity Corps: https://europa.eu/youth/solidarity_en. Accessed: 09/04/2017.

[18]Law on Employment Promotion in the Republic of Bulgaria: http://lex.bg/laws/ldoc/-12262909.

Accessed: 09/04/2017.

[19] National Action Plan on Employment for 2017. Republic of Bulgaria: https://www.mlsp.government.bg/index.php ?section=POLICIESI $\&$ I=249. Accessed: 09/04/2017.

[20]National Development Programme: Bulgaria 2020: http://www.minfin.bg/en/page/869. Accessed: 09/04/2017.

[21]National Plan for implementing the European Youth Guarantee 2014-2020: http://www.strategy.bg/StrategicDocuments /View.aspx ?lang=bg-BG\&Id=883. Accessed: 09/04/2017.

[22] National Reform Program of the Republic of Bulgaria 2016-2020: http://www.minfin.bg/en/page/867. Accessed: 09/04/2017.

[23] National Strategy for Lifelong Learning 2014-2020:

http://www.strategy.bg/StrategicDocuments /View.aspx?lang=bg-BG\&Id=880.

Accessed: 09/04/2017.

[24]National Strategy for Persons with Disabilities 2016-2020: http://www.government.bg/cgi-bin/e$\mathrm{cms} / \mathrm{vis} / \mathrm{vis} . \mathrm{pl}$ ? $=001 \& \mathrm{p}=0228 \& \mathrm{n}=8371 \& \mathrm{~g}$ =. Accessed: 09/04/2017.

[25] Terziev, V., Arabska, E. (2015a). Analyses of labor market development in Bulgaria: role of active policies for social and economic development. 3rd HASSACC 2015 - Virtual Conference Human and Social Sciences at the Common Conference, 5-9 October, 2015, pp. 140145.

[26]Terziev, V., Arabska, E. (2015b). Application of new instruments to increase effectiveness of implementation of social policies on labor market in Bulgaria. Journal of economic development, environment and people (JEDEP), Vol. 4, No 3 (2015), pp. 26-44.

[27] Terziev, V., Arabska, E. (2015c). Bulgarian experience in labor market development. $18^{\text {th }}$ International Academic Conference, 25 August 2015, London, IISES, pp. 710-733.

[28]Terziev, V., Arabska, E. (2015d). Connecting jobseekers and employers and 
more: the contributions of PES to EU social and economic development. 19th International Academic Conference, Florence, 16-19 September, 2015, IISES, pp. 859-873.

[29]Terziev, V., Dimitrova, S. (2014). Development and restructuring of employment in Bulgaria in the period of transition and active transformations. New knowledge Journal of science, 3(3), pp. 1929.

[30]Terziev, V., Dimitrova, S. (2015). Peculiarities of labor market development in the Republic of Bulgaria, Journal of Innovations and Sustainability, Vol. 1, No 1, 2015, pp. 47-99.
[31]Terziev, V., Dimitrova, S., Arabska, E. (2015). Assessment of active social policies' impacts on labor market in a period of transformation Bulgarian society. Procedia Economics and Finance 30 (2015) $890-902$.

[32] Terziev, V., Dimitrova, S., Stoyanov, E. (2015). Development of active social programs, Journal of Innovations and Sustainability, Vol. 1, No 1, 2015, pp. 2746.

[33]Updated Employment Strategy of the Republic of Bulgaria 2013-2020: http://www.strategy.bg/StrategicDocuments $/$ View.aspx ?lang=bg-BG\&Id=858.

Accessed: 09/04/2017. 